\title{
ESR1 polymorphism (rs2234693) influences femoral bone mass in patients with Turner syndrome
}

\author{
Renata C Scalco ${ }^{1,2,3}$, Ericka B Trarbach ${ }^{1}$, Edoarda V A Albuquerque ${ }^{1}$, Thais K Homma ${ }^{1}$, Thais H Inoue-Lima ${ }^{1}$, \\ Mirian Y Nishi ${ }^{3}$, Berenice B Mendonca ${ }^{3}$ and Alexander A L Jorge ${ }^{1}$

\begin{abstract}
${ }^{1}$ Unidade de Endocrinologia Genetica, Laboratorio de Endocrinologia Celular e Molecular LIM/25, Disciplina de Endocrinologia, Faculdade de Medicina, Universidade de São Paulo, São Paulo, São Paulo, Brazil

2Disciplina de Endocrinologia, Faculdade de Ciências Médicas da Santa Casa de São Paulo, São Paulo, São Paulo, Brazil

${ }^{3}$ Unidade de Endocrinologia do Desenvolvimento, Laboratorio de Hormonios e Genetica Molecular LIM/42, Disciplina de Endocrinologia, Faculdade de

Medicina, Universidade de São Paulo, São Paulo, São Paulo, Brazil
\end{abstract}

Correspondence should be addressed to R C Scalco: rescalco@gmail.com

\begin{abstract}
Most patients with Turner syndrome (TS) need hormone replacement therapy because of hypergonadotropic hypogonadism; individual outcomes, however, are highly variable. Our objective was to assess the influence of five estrogen receptor 1 gene (ESR1) polymorphisms (rs543650, rs1038304, rs2046210, rs2234693 and rs9340799) on adult height, breast development, uterine volume and bone mineral density (BMD). We studied 91 TS patients from a tertiary hospital using adult estrogen dose. In our group, ESR1 rs2234693 was associated with femoral neck and total hip BMD, and it accounted for around $10 \%$ of BMD variability in both sites $(P<0.01)$. Patients homozygous for $C$ allele in this polymorphism had significantly lower femoral neck BMD $\left(0.699 \pm 0.065 \mathrm{~g} / \mathrm{cm}^{2}\right.$ vs $\left.0.822 \pm 0.113 \mathrm{~g} / \mathrm{cm}^{2}, P=0.008\right)$ and total hip BMD $\left(0.777 \pm 0.118 \mathrm{~g} / \mathrm{cm}^{2}\right.$ vs $0.903 \pm 0.098 \mathrm{~g} / \mathrm{cm}^{2}, P=0.009$ ) than patients homozygous for T allele. The other four ESR1 polymorphisms were not able to predict any of the above estrogen therapy outcomes in an isolated manner. Patients homozygous for the haplotype GCG formed by polymorphisms rs543650, rs2234693 and rs9340799 had an even more significantly lower femoral neck BMD $\left(0.666 \pm 0.049\right.$ vs $\left.0.820 \pm 0.105 \mathrm{~g} / \mathrm{cm}^{2}, P=0.0047\right)$ and total hip BMD $(0.752 \pm 0.093$ vs $0.908 \pm 0.097 \mathrm{~g} / \mathrm{cm}^{2}, P=0.0029$ ) than patients homozygous for haplotypes with a T allele in rs2234693. In conclusion, homozygosity for C allele in ESR1 rs2234693 and/or for GCG haplotype appears to be associated with lower femoral neck and total hip BMD. We believe that the identification of polymorphisms related to estrogen outcomes may contribute to individualization of treatment in TS.
\end{abstract}
Key Words
- Turner syndrome
- estrogen receptor
- hormone replacement therapy
- polymorphisms
- association study

\section{Introduction}

Turner syndrome (TS) is characterized by complete or partial absence of the second sex chromosome in phenotypic females with one or more clinical manifestations (1). It is one of the most common chromosomal abnormalities, affecting approximately 25-50 per 100,000 females. Hypergonadotropic hypogonadism is a frequent manifestation, present in more than $95 \%$ of TS patients. Therefore, most patients will need hormone replacement therapy (HRT) for puberty induction, attaining of peak bone mass and maintenance of female secondary sex characteristics (1). 
However, individual outcomes of estrogen treatment are highly variable among these patients. For instance, uterine development descriptions range from lower than average even with adequate HRT (2) to normal in all treated patients (3). This feature was previously associated with diverse factors such as the presence of spontaneous puberty (4), duration of HRT $(4,5)$, dose of $\operatorname{HRT}(5,6)$, type of HRT (4) and karyotype (7). Nevertheless, there are controversies among studies and none of these factors can thoroughly explain the interindividual variation.

Genome-wide association studies (GWAS) showed that polymorphisms in estrogen receptor 1 gene (ESR1) participate in the variability of many characteristics, such as height, bone density, breast size and risk of cancer $(8,9,10,11)$. There is only one study involving TS patients that showed an association between two ESR1 polymorphisms and bone mass gain with estrogen therapy (12). To our knowledge, there are no data on the impact of ESR1 polymorphisms on height variability or on the development of secondary sex characteristics in these patients. Thus, the aim of this study was to assess the influence of ESR1 polymorphisms on estrogen therapy outcomes in TS patients.

\section{Patients and methods}

\section{Subjects}

The study protocol was approved by the Research Ethics Committee of the Hospital das Clinicas da Faculdade de Medicina da Universidade de Sao Paulo. Written informed consent was obtained from all patients before starting the molecular studies. Ninety-one TS patients from our endocrinology clinic were selected using the following criteria: (1) regular use of adult estrogen dose (i.e. at least $1 \mathrm{mg}$ of estradiol valerate daily or equivalent) for a minimum period of one year; (2) absence of spontaneous menarche; and (3) absence of Y chromosome material in karyotype. These patients were submitted to clinical evaluation for height and breast development (according to Tanner staging), pelvic ultrasound for assessment of uterine volume, and dual-energy X-ray absorptiometry (DEXA) for determination of bone mineral density at lumbar spine and proximal femur. Since DEXA has a known tendency to underestimate the bone density of people with short stature, we calculated bone mineral apparent density (BMAD) by using bone mineral content and projected bone area (13).

\section{Cytogenetic study}

Karyotype data were collected from medical records. Twenty to fifty cells were evaluated. Metaphase spreads prepared from peripheral lymphocyte cultures from each patient were studied by conventional staining and $G$ and $\mathrm{C}$ banding techniques and were analyzed through an optical microscope (Carl Zeiss). Patients with chromosome fragments or rings of unidentified origin were evaluated for the presence of Y-chromosomal material with realtime PCR with multiple Y-specific probes, according to a previously described protocol (5).

\section{ESR1 polymorphisms}

ESR1 polymorphisms were selected through active search in PubMed and in GWAS catalogs. We chose five polymorphisms that were recurrent in studies or that were Tag-single nucleotide polymorphisms (Tag-SNPs), provided that they had a minor allele frequency (MAF) which allowed the present study with the available sample. Two of them are well-known ESR1 polymorphisms (rs2234693 and rs9340799) and the others were previously found to influence height (rs543650) (8), bone mineral density (rs1038304) (9) or risk of breast cancer (rs2046210) (11) in GWAS.

\section{Molecular studies}

Genomic DNA was isolated from peripheral blood leukocytes by standard methods from all patients. The ESR1 polymorphisms were genotyped by allelic discrimination using specific TaqMan probes and primers in the Step One Plus Real-Time PCR system (Applied Biosystems) according to manufacturer's instructions. Ten percent of all samples were randomly selected and sequenced by Sanger for quality control. Briefly, PCR amplification was performed using GoTaq Green PCR systems (Promega) with $25 \mathrm{ng}$ of DNA, $1 \times$ buffer, $10 \mathrm{mM}$ dNTP, $0.2 \mathrm{mM}$ of each forward and reverse primers and $1 \mathrm{U}$ of enzyme, in a final $15 \mu \mathrm{L}$ reaction mixture (Table 1 ). PCR cycling conditions were as follows: $98^{\circ} \mathrm{C}$ for $5 \mathrm{~min}$, followed by 30 cycles of $95^{\circ} \mathrm{C}$ for $30 \mathrm{~min}, 56^{\circ} \mathrm{C}$ of annealing temperature for $45 \mathrm{~min}$ and $72^{\circ} \mathrm{C}$ for $30 \mathrm{~min}$; and $10 \mathrm{~min}$ of final elongation step at $72^{\circ} \mathrm{C}$. Subsequently, the PCR products were sequenced using BigDye Terminator v3.1 cycle sequencing protocol in the ABI PRISM 310 automatic sequencer (Thermo Fisher). The agreement of genotyping between both methods was $100 \%$. 
Table 1 List of TaqMan assays and PCR primers used in this study.

\begin{tabular}{|c|c|c|c|c|}
\hline \multirow[b]{2}{*}{ ESR1 SNPS } & \multirow[b]{2}{*}{ TaqMan assay ID } & \multicolumn{2}{|c|}{ PCR primer sequences ( $5^{\prime}$ to $3^{\prime}$ ) } & \multirow[b]{2}{*}{ PCR amplicon (pb) } \\
\hline & & Forward & Reverse & \\
\hline rs2234693a & C_3163590-10 & CATGAACCACCATGCTCAGT & AAAAACATACTACCTGCACCAGAA & 388 \\
\hline rs9340799a & C_3163591-10 & & & \\
\hline rs543650 & C_551076-10 & TCCCTGGAGGAAACGTAAAA & TCCCAACACCTTCCAGACTC & 360 \\
\hline rs1038304 & C_219719-10 & CCTGAGTAGCCGGGAGTACA & AGTCTGAGGAATGGGAGCAA & 359 \\
\hline rs2046210 & C12034236-10 & GTGGGTCAAGACCAGCATTT & CCATCGTCCACATCTCACAC & 337 \\
\hline
\end{tabular}

aBoth SNPs were PCR genotyped in the same amplicon.

\section{Statistical analysis}

In this study, we evaluated the association among ESR1 polymorphisms and the following outcomes: adult height, breast development, uterine volume and bone mineral density at lumbar spine and proximal femur. Qualitative variables are listed as percentages, whereas quantitative variables are shown as mean \pm s.D. Nominal variables were compared with chi-square test or Fisher exact test, as appropriate. Numerical variables were analyzed using t-test, Mann-Whitney rank-sum test or Kruskal-Wallis one-way ANOVA on ranks, as appropriate. To assess whether genetic variants had independent prognostic significance for outcomes, we performed linear and multiple-regression analyses adjusting for established influential factors. Since we tested associations with clinical parameters for multiple SNPs $(n=5)$, we applied Bonferroni's correction for the $P$ values and only associations with $P$ value $<0.01$ were considered significant. Haplotype blocks were constructed by using the Solid Spine method from the software Haploview (14) and their association with estrogen outcomes was also assessed. All statistical analyses were performed using SigmaStat for Windows (version 3.5).

\section{Results}

We evaluated 91 TS patients aged 25.1 \pm 6.8 years old (range 16 to 42 years old) (Table 2). 45,X karyotype was the most frequently found $(n=55,60 \%)$, followed by $46, \mathrm{XiXq}$ with or without mosaicism $(n=12)$, other structural abnormalities $(n=7), 45, \mathrm{X} / 46, \mathrm{XX}(n=6)$, ring $\mathrm{X}$ chromosome mosaicisms $(n=6), 45, \mathrm{X} / 47, \mathrm{XXX}(n=3)$, marker chromosome mosaicisms $(n=2)$. Eighty-three percent of them received recombinant human growth hormone $(\mathrm{rhGH})$ treatment for a mean duration of $6.3 \pm 3.1$ years, starting at $9.9 \pm 4.0$ years old. Their mean adult height was $148.4 \pm 6.9 \mathrm{~cm}$. Their age at puberty onset or induction was $14.3 \pm 1.9$ years old and $9 \%$ of

them had spontaneous thelarche. Uterine volume had a wide range, from 5.9 to $107 \mathrm{~cm}^{3}$ (mean $31.3 \pm 18.4 \mathrm{~cm}^{3}$ ). Ninety percent of patients reached Tanner stage 5 breast development. Eighty percent of patients had normal bone mass after calculation of BMAD based on bone mineral content and projected bone area.

All patients were genotyped for the five selected ESR1 polymorphisms: rs543650, rs1038304, rs2046210, rs2234693 and rs9340799. We did not detect deviations from the Hardy-Weinberg equilibrium in their genotype distributions. We first evaluated the association among these polymorphisms and adult height, uterine volume, breast development and bone density by using linear regression. ESR1 rs2234693, also known as PvuII (after the name of the restriction enzyme initially used to study it)

Table 2 Clinical and radiological data from 91 Turner syndrome patients.

Basal characteristics

45,X karyotype

Target height

Use of rhGH

Age at rhGH onset

Duration of rhGH use

Age at puberty onset or induction

Spontaneous thelarche

Current data

Age

Adult height

Breast development (Tanner staging)

Uterine volume

Normal bone mass in lumbar spine (BMD)

Normal bone mass in lumbar spine (BMAD)

Normal bone mass in femoral neck (BMD)

Normal bone mass in femoral neck (BMAD)

$60 \%$

$158.6 \pm 4.7 \mathrm{~cm}$

$83 \%$

$9.9 \pm 4.0$ years

$6.3 \pm 3.1$ years

$14.3 \pm 1.9$ years old

$9 \%$

$25.1 \pm 6.8$ years old

$148.4 \pm 6.9 \mathrm{~cm}$

B5 90\%

$31.3 \pm 18.4 \mathrm{~cm}^{3}$

$68 \%$

$80 \%$

$80 \%$

$96.5 \%$

Qualitative variables are listed as percentages, whereas quantitative variables are shown as mean \pm S.D.

B5, Tanner 5 breast development; BMAD, bone mineral apparent density; $\mathrm{BMD}$, bone mineral density; rhGH, recombinant human growth hormone. 
Table 3 Linear regressions among five ESR1 polymorphisms and selected estrogen replacement outcomes ( $P$ values).

\begin{tabular}{lcc}
\hline ESR1 polymorphisms & & rs543650 \\
\cline { 1 - 1 } Adult height & & 0.318 \\
Breast development & & 0.719 \\
Femoral neck BMD & & 0.558 \\
Femoral neck BMAD & & 0.768 \\
Lumbar spine BMD & & 0.936 \\
Lumbar spine BMAD & & 0.289 \\
Total hip BMD & 0.958 \\
Uterine volume & 0.998 \\
\hline
\end{tabular}

\begin{tabular}{c}
\hline rs1038304 \\
\hline 0.89 \\
0.1 \\
0.789 \\
0.129 \\
0.063 \\
0.375 \\
0.908 \\
0.643 \\
\hline
\end{tabular}

\begin{tabular}{c}
\hline rs2046210 \\
\hline 0.831 \\
0.154 \\
0.395 \\
0.266 \\
0.074 \\
0.301 \\
0.606 \\
0.445 \\
\hline
\end{tabular}

\begin{tabular}{c}
\hline rs2234693 \\
\hline 0.129 \\
0.495 \\
$\mathbf{0 . 0 0 7}\left(R^{2}=0.107\right)$ \\
0.025 \\
0.364 \\
0.280 \\
$\mathbf{0 . 0 0 9}\left(R^{2}=0.108\right)$ \\
0.171
\end{tabular}

\begin{tabular}{c}
\hline rs9340799 \\
\hline 0.218 \\
0.687 \\
0.16 \\
0.352 \\
0.158 \\
0.437 \\
0.08 \\
0.851
\end{tabular}

Only associations with $P<0.01$ were considered significant after application of Bonferroni's correction.

$B M A D$, bone mineral apparent density; BMD, bone mineral density; ESR1, estrogen receptor 1 gene; ns, not significant.

was associated with femoral neck and total hip BMD, and it accounted for around 10\% of BMD variability in these sites (Table 3). This polymorphism was not related to adult height, uterine volume, breast development and lumbar spine BMD or BMAD in our patients. The other four ESR1 polymorphisms were not able to predict any of the above estrogen therapy outcomes in an isolated manner.

ESR1 rs2234693 distribution was C/C 14\%, C/T $57 \%$ and $\mathrm{T} / \mathrm{T}$ 29\%. Genotypic groups were similar concerning karyotype distribution, target height, use of rhGH treatment, age at rhGH onset and duration of treatment, age at puberty onset/induction and frequency of spontaneous thelarche (Table 4). There were also no significant differences concerning estrogen dose, adult height, uterine volume, breast development according to Tanner staging or lumbar spine BMD and BMAD. However, femoral neck and total hip BMD were significantly different among the groups, and these differences were due to a significantly lower BMD in both sites in patients homozygous for $\mathrm{C}$ allele in comparison to patients homozygous for T allele.

ESR1 rs2234693 was located in a linkage disequilibrium block with rs543650 and rs9340799 (Fig. 1). The most common haplotypes were TTA $(32.5 \%$, formed by a T allele in ESR1 rs543650, a T allele in rs2234693 and an A allele in rs9340799), followed by GCG (31.1\%), GTA (22.9\%) and GCA (11.2\%). ESR1 rs1038304 and rs2046211 were located in another linkage disequilibrium block nearby. HRT outcomes were compared among haplotypes,

Table 4 Clinical and radiological data from 91 Turner syndrome patients grouped according to ESR1 rs2234693 genotype.

\begin{tabular}{l}
\hline \\
\hline Number of patients \\
$45, X$ karyotype \\
Target height (cm) \\
Use of rhGH \\
Age at rhGH onset (years) \\
Duration of rhGH use (years) \\
Age at puberty onset or induction (years) \\
Spontaneous thelarche \\
Adult height (cm) \\
Breast development (Tanner) \\
Estradiol valerate or equivalent dose (mg/day) \\
Femoral neck BMAD (g/cm $\left.{ }^{3}\right)$ \\
Femoral neck BMD (g/cm $\left.{ }^{2}\right)$ \\
Lumbar spine BMD $\left(\mathrm{g} / \mathrm{cm}^{2}\right)$ \\
Lumbar spine BMAD $\left(\mathrm{g} / \mathrm{cm}^{3}\right)$ \\
Total hip BMD $\left(\mathrm{g} / \mathrm{cm}^{2}\right)$ \\
Uterine volume $\left(\mathrm{cc}^{3}\right)^{\mathrm{e}}$
\end{tabular}

\begin{tabular}{|c|c|}
\hline $\mathrm{C} / \mathrm{C}$ & $C / T$ \\
\hline 13 & 52 \\
\hline $61 \%$ & $65 \%$ \\
\hline $159.9 \pm 4.2$ & $158.9 \pm 5.1$ \\
\hline $92 \%$ & $83 \%$ \\
\hline $11.1 \pm 4.1$ & $9.7 \pm 4.0$ \\
\hline $5.7 \pm 3.3$ & $6.3 \pm 3.0$ \\
\hline $14.7 \pm 1.6$ & $14.2 \pm 2.0$ \\
\hline $7.7 \%$ & $9.6 \%$ \\
\hline $151 \pm 5.4$ & $148.3 \pm 6.8$ \\
\hline M5 85\% & M5 86\% \\
\hline $1.1 \pm 0.6$ & $1.4 \pm 0.5$ \\
\hline $0.150 \pm 0.017$ & $0.167 \pm 0.028$ \\
\hline $0.699 \pm 0.065$ & $0.760 \pm 0.119$ \\
\hline $0.867 \pm 0.122$ & $0.898 \pm 0.142$ \\
\hline $0.154 \pm 0.040$ & $0.146 \pm 0.020$ \\
\hline $0.777 \pm 0.118$ & $0.857 \pm 0.111$ \\
\hline $29.9 \pm 17.8$ & $29.0 \pm 16.5$ \\
\hline $29.5(8.0-76.2)$ & $25.2(5.9-82.9)$ \\
\hline
\end{tabular}

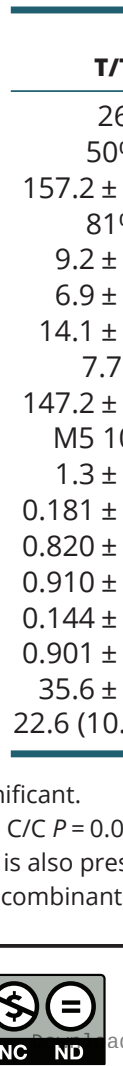

$\mathbf{T} / \mathbf{T}$

26

$50 \%$

$2 \pm 4.0$

$2.2 \pm 3.9$

$6.9 \pm 3.4$

$4.1 \pm 1.9$

$7.7 \%$

$47.2 \pm 7.8$

M5 100\%

$1.3 \pm 0.4$

$0.181 \pm 0.037$

$0.820 \pm 0.110$

$0.910 \pm 0.124$

$0.144 \pm 0.014$

$0.901 \pm 0.096$

$35.6 \pm 22.6$ $29.5(8.0-76.2)$

Only associations with $P<0.01$ after application of Bonferroni's correction were considered significant.

a One-way ANOVA or chi-square/Fisher. ${ }^{\mathrm{b}}{ }^{\mathrm{a}}$ test or chi-square/Fisher. ${ }^{\mathrm{C}} \mathrm{Holm}-\mathrm{Sidak}$ method: $\mathrm{T} / \mathrm{T}$ vs $\mathrm{C} / \mathrm{C} P=0.0111 ; \mathrm{T} / \mathrm{T}$ vs $\mathrm{C} / \mathrm{T}$ ns; $\mathrm{C} / \mathrm{T}$ vs $\mathrm{C} / \mathrm{C}$ ns. ${ }^{\mathrm{d}} \mathrm{Holm}-\mathrm{Sidak}$ method: $\mathrm{T} / \mathrm{T}$ vs $\mathrm{C} / \mathrm{C} P=0.00786 ; \mathrm{T} / \mathrm{T}$ vs $\mathrm{C} / \mathrm{T}$ ns; $\mathrm{C} / \mathrm{T}$ vs $\mathrm{C} / \mathrm{C}$ ns. ${ }^{\mathrm{e}}$ For its wide range, uterine volume is also presented as median (minimum-maximum). $\mathrm{BMAD}$, bone mineral apparent density; BMD, bone mineral density; ns, not significant; rhGH, recombinant human growth hormone.

https://ec.bioscientifica.com https://doi.org/10.1530/EC-19-0398 (c) 2019 The authors Published by Bioscientifica Ltd

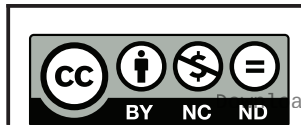

This work is licensed under a Creative Commons Attribution-NonCommercial-NoDerivatives 4.0 Internationab bicense.ifica. com at 04/26/2023 11:07:01AM 


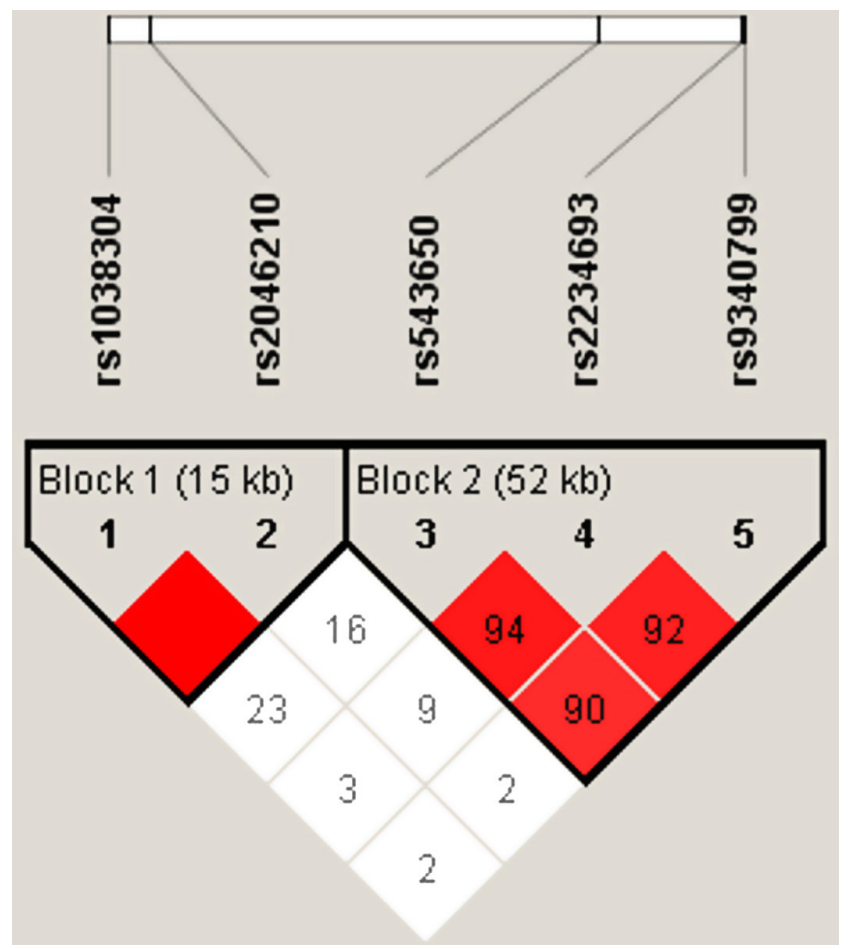

\section{Figure 1}

Haploview linkage disequilibrium plot for five selected SNPs within ESR1. Haplotype blocks were constructed by using the Solid Spine method. ESR1 rs2234693 was located in a linkage disequilibrium block with rs543650 and rs9340799. ESR1 rs1038304 and rs2046211 were located in another linkage disequilibrium block nearby.

and patients homozygous for the haplotype GCG had significantly lower femoral neck BMD and total hip BMD than patients homozygous for haplotypes with a $\mathrm{T}$ allele in rs2234693 (Table 5). It was not possible to compare patients homozygous for GCG haplotype with patients homozygous for other haplotypes containing a $\mathrm{C}$ allele in rs2234693 because there was only one patient with this latter haplotype. None of the haplotypes was linked to adult height, uterine volume or L1-L4 BMD.

\section{Discussion}

Polymorphisms influence physiological, morphological and pathological variation in the human population (15). In TS, polymorphisms in the growth hormone receptor gene $(G H R)(16,17)$ and the insulin-like growth factorbinding protein 3 gene (IGFBP3) (16) were correlated with increased responsiveness to rhGH treatment $(16,17)$ and adult height (16). One polymorphism in the suppressor of cytokine signaling 2 gene (SOCS2) was also linked to adult height after rhGH treatment (18). Furthermore, polymorphisms in the protein tyrosine phosphatase nonreceptor type 2 gene (PTPN22) (19) and the myosin IXB gene $(M Y O 9 B)(20)$ were associated with a higher risk of autoimmune diseases; polymorphisms in the vitamin $\mathrm{D}$ receptor gene $(V D R)$ were related to lower $\mathrm{BMD}$ and higher levels of bone markers (21); and a polymorphism in the cytotoxic T lymphocyte-associated protein 4 gene (CTLA-4) was linked to obesity in these patients (22). Finally, ESR1 rs2234693 and rs9340799 were associated with bone mass gain in lumbar spine after the onset of estrogen replacement in adult TS patients (12).

In the present study, we found that TS patients homozygous for C allele in ESR1 rs2234693 had lower femoral neck and total hip BMD than TS patients homozygous for $\mathrm{T}$ allele. Additionally, patients homozygous for the haplotype GCG formed by polymorphisms rs543650, rs2234693 and rs9340799 had an even more significantly lower femoral neck BMD and total hip BMD than patients homozygous for haplotypes with a T allele in rs2234693. Similar results were found in two other studies involving young premenopausal healthy patients $(23,24)$. Massart et al. found that, in a group of Italian women aged between 20 and 30 years old, the presence of at least one C allele in rs2234693 was associated with lower lumbar spine and proximal femur BMD (23). Furthermore, McGuigan et al. showed that,

Table 5 Comparison of bone mass data among Turner syndrome patients grouped according to ESR1 haplotypes (involving rs543650, rs2234693 and rs9340799).

\begin{tabular}{|c|c|c|c|c|c|c|}
\hline & $\begin{array}{c}\text { Homozygous } \\
\text { GCG }(n=8)\end{array}$ & $\begin{array}{c}\text { Heterozygous } \\
\text { GCG }(n=38)\end{array}$ & $\begin{array}{c}\mathbf{x C x} \text { (except GCG) } \\
(n=20)\end{array}$ & $\begin{array}{c}\text { Homozygous } \\
\mathbf{x T} \mathbf{x}(n=25)\end{array}$ & $\begin{array}{l}\text { P value } \\
\text { all groups }\end{array}$ & $\begin{array}{c}\text { P value } \\
\text { homozygous GCG vs } \\
\text { homozygous xTx }\end{array}$ \\
\hline Femoral neck BMD (g/cm²) & $0.666 \pm 0.049$ & $0.766 \pm 0.117$ & $0.775 \pm 0.123$ & $0.820 \pm 0.105$ & 0.039 & 0.0047 \\
\hline Lumbar spine BMD (g/cm²) & $0.846 \pm 0.103$ & $0.884 \pm 0.131$ & $0.947 \pm 0.147$ & $0.889 \pm 0.134$ & 0.224 & 0.417 \\
\hline Total hip BMD (g/cm²) & $0.752 \pm 0.093$ & $0.852 \pm 0.099$ & $0.869 \pm 0.132$ & $0.908 \pm 0.097$ & 0.025 & 0.0029 \\
\hline
\end{tabular}

BMD, bone mineral density; heterozygous GCG, patients heterozygous for the haplotype formed by a G allele in ESR1 rs543650, a C allele in rs2234693 and a G allele in rs9340799; homozygous GCG, patients homozygous for the haplotype formed by a G allele in ESR1 rs543650, a C allele in rs2234693 and a G allele in rs9340799; homozygous xTx, patients homozygous for haplotypes formed by any allele in ESR1 rs543650, a T allele in rs2234693 and any allele in rs9340799; ns, not significant; xCx, patients heterozygous (and 1 homozygous) for haplotypes formed by any allele in ESR1 rs543650, a C allele in rs2234693 and any allele in rs9340799.

https://ec.bioscientifica.com https://doi.org/10.1530/EC-19-0398 (c) 2019 The authors Published by Bioscientifica Ltd

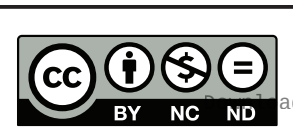

This work is licensed under a Creative Commons Attribution-NonCommercial-NoDerivatives 4.0 Internationab sicense.ifica . com at 04/26/2023 11:07:01AM 
in a group of Irish women around 22 years old, homozygosity for T allele in ESR1 rs2234693 was related to higher hip BMD (24). Our results are also aligned to those of the previous study on bone mass gain after the onset of estrogen replacement in TS patients (12), which showed significant bone gain in lumbar spine in patients who had at least one T allele in ESR1 rs2234693 and/or one A allele in ESR1 rs9340799 but not in patients homozygous for C allele in ESR1 rs2234693 and/or homozygous for G allele in ESR1 rs9340799. Unfortunately, proximal femur BMD was not evaluated in that study.

Briefly, estrogens increase bone formation at the periosteum through its action in osteoblast progenitors and suppress bone resorption in trabecular and endocortical bone surfaces by decreasing osteoclast numbers. These actions are mainly mediated by estrogen receptor 1 (ER1) nuclear and non-nuclear initiated signaling pathways. However, the molecular details by which ER1 signaling influences bone mass remain unclear (25). In a in vitro model using renal cells, Herrington et al. showed that the presence of a C allele in ESR 1 rs2234693 produces a potential binding site for myb transcription factors in ER1, and might produce ER1 isoforms that have different properties than the full-length gene product (26). If the presence of a C allele in ESR1 rs2234693 reduces ER1 function in bone, this could explain why TS patients who were homozygous for this allele had lower bone mass gain with estrogen replacement (12). Moreover, it could also explain the lower femoral neck and total hip BMD seen in young women with this genotype. The reason for the lack of association between this allele and lumbar spine BMD in our study and in McGuigan's (24) is still unclear but could be probably explained by the relatively small size of both studies.

Other factors that could have influenced bone mass, such as use and duration of rhGH treatment, age at puberty onset/induction or estrogen dose, were not significantly different among genotypic groups. Karyotype is considered not to be associated with BMD or fracture risk by most groups (1), and was not linked to bone mass in our patients either. Limitations of our study include its small size and absence of a replication analysis in young Brazilian women without TS. Consequently, further studies, preferably prospective and multicenter, with a larger number of TS patients and healthy young controls are necessary to confirm our findings. On the other hand, this was the first study to evaluate the association of an ESR1 polymorphism to bone mass in TS patients already receiving adult-dose estrogen replacement therapy. Moreover, the presence of a similar association in other groups of young women with and without TS strengthens our result and suggests a potential contribution of ESR1 rs2234693 to bone mass acquisition. Finally, although we could not find associations among ESR1 polymorphisms and adult height, breast development and uterine volume, the high variability especially of the latter suggests that genetic variants play an important role. More efforts to identify polymorphisms associated with estrogen outcomes may allow for individualization of treatment in TS.

\section{Declaration of interest}

Merck has performed a scientific review of the publication, but the views and opinions described in the publication do not necessarily reflect those of Merck.

\section{Funding}

This study was supported by Grant for Growth Innovation from Merck KGaA, Darmstadt, Germany and by Grants 2016/03318-0 (to R C S) and 2013/03236-5 (to A A L J) from São Paulo Research Foundation (FAPESP).

\section{References}

1 Gravholt CH, Andersen NH, Conway GS, Dekkers OM, Geffner ME, Klein KO, Lin AE, Mauras N, Quigley CA, Rubin K, et al. Clinical practice guidelines for the care of girls and women with Turner syndrome: proceedings from the 2016 Cincinnati International Turner Syndrome Meeting. European Journal of Endocrinology 2017 177 G1-G70. (https://doi.org/10.1530/EJE-17-0430)

2 Cleemann L, Holm K, Fallentin E, Skouby SO, Smedegaard H, Møller N, Borch-Christensen H, Jeppesen EM, Wieslander SB, Andersson AM, et al. Uterus and ovaries in girls and young women with Turner syndrome evaluated by ultrasound and magnetic resonance imaging. Clinical Endocrinology 2011 74 756-761. (https:// doi.org/10.1111/j.1365-2265.2011.03995.x)

3 McDonnell CM, Coleman L \& Zacharin MR. A 3-year prospective study to assess uterine growth in girls with Turner's syndrome by pelvic ultrasound. Clinical Endocrinology 200358 446-450. (https:// doi.org/10.1046/j.1365-2265.2003.01737.x)

4 Bakalov VK, Shawker T, Ceniceros I \& Bondy CA. Uterine development in Turner syndrome. Journal of Pediatrics $2007 \mathbf{1 5 1} 528$. e1-531.e1. (https://doi.org/10.1016/j.jpeds.2007.04.031)

5 Elsedfy HH, Hamza RT, Farghaly MH \& Ghazy MS. Uterine development in patients with Turner syndrome: relation to hormone replacement therapy and karyotype. Journal of Pediatric Endocrinology and Metabolism 201225 441-445. (https://doi.org/10.1515/jpem2012-0040)

6 Snajderova M, Mardesic T, Lebl J, Gerzova H, Teslik L, Zapletalova J \& Czech National Study Group for HRT Optimization in Paediatric and Adolescent Endocrinology and Gynaecology. The uterine length in women with Turner syndrome reflects the postmenarcheal daily estrogen dose. Hormone Research 200360 198-204. (https://doi. org/10.1159/000073233)

7 Doerr HG, Bettendorf M, Hauffa BP, Mehls O, Partsch CJ, Said E, Sander S, Schwarz HP, Stahnke N, Steinkamp H, et al. Uterine size in women with Turner syndrome after induction of puberty with estrogens and long-term growth hormone therapy: results of the German IGLU Follow-up Study 2001. Human Reproduction 200520 1418-1421. (https://doi.org/10.1093/humrep/deh764) 
8 Lango Allen H, Estrada K, Lettre G, Berndt SI, Weedon MN, Rivadeneira F, Willer CJ, Jackson AU, Vedantam S, Raychaudhuri S, et al. Hundreds of variants clustered in genomic loci and biological pathways affect human height. Nature 2010467 832-838. (https:// doi.org/10.1038/nature09410)

9 Styrkarsdottir U, Halldorsson BV, Gretarsdottir S, Gudbjartsson DF, Walters GB, Ingvarsson T, Jonsdottir T, Saemundsdottir J, Center JR, Nguyen TV, et al. Multiple genetic loci for bone mineral density and fractures. New England Journal of Medicine 2008358 2355-2365. (https://doi.org/10.1056/NEJMoa0801197)

10 Eriksson N, Benton GM, Do CB, Kiefer AK, Mountain JL, Hinds DA, Francke U \& Tung JY. Genetic variants associated with breast size also influence breast cancer risk. BMC Medical Genetics 20121353. (https://doi.org/10.1186/1471-2350-13-53)

11 Garcia-Closas M, Couch FJ, Lindstrom S, Michailidou K, Schmidt MK, Brook MN, Orr N, Rhie SK, Riboli E, Feigelson HS, et al. Genomewide association studies identify four ER negative-specific breast cancer risk loci. Nature Genetics 201345 392.e1-398.e1. (https://doi. org/10.1038/ng.2561)

12 Sowińska-Przepiera E, Andrysiak-Mamos E, Chełstowski K, Adler G, Friebe Z \& Syrenicz A. Association between ER- $\alpha$ polymorphisms and bone mineral density in patients with Turner syndrome subjected to estroprogestagen treatment - a pilot study. Journal of Bone and Mineral Metabolism 201129 484-492. (https://doi.org/10.1007/s00774-0100247-3)

13 Bakalov VK \& Bondy CA. Fracture risk and bone mineral density in Turner syndrome. Reviews in Endocrine and Metabolic Disorders 20089 145-151. (https://doi.org/10.1007/s11154-008-9076-2)

14 Barrett JC, Fry B, Maller J \& Daly MJ. Haploview: analysis and visualization of LD and haplotype maps. Bioinformatics 200521 263-265. (https://doi.org/10.1093/bioinformatics/bth457)

15 Wright AF. Genetic Variation: Polymorphisms and Mutations. Encyclopedia Of Life Sciences. Hoboken NJ, USA: John Wiley \& Sons, 2005. (https://doi.org/10.1038/npg.els.0005005)

16 Braz AF, Costalonga EF, Montenegro LR, Trarbach EB, Antonini SR, Malaquias AC, Ramos ES, Mendonca BB, Arnhold IJ \& Jorge AAL. The interactive effect of GHR-exon 3 and -202 A/C IGFBP3 polymorphisms on rhGH responsiveness and treatment outcomes in patients with Turner syndrome. Journal of Clinical Endocrinology and Metabolism 2012 97 E671-E677. (https://doi.org/10.1210/jc.2011-2521)

17 Binder G, Baur F, Schweizer R \& Ranke MB. The d3-growth hormone (GH) receptor polymorphism is associated with increased responsiveness to GH in Turner syndrome and short small-forgestational-age children. Journal of Clinical Endocrinology and Metabolism 200691 659-664. (https://doi.org/10.1210/jc.2005-1581)

18 Braz AF, Costalonga EF, Trarbach EB, Scalco RC, Malaquias AC, Guerra-Junior G, Antonini SR, Mendonca BB, Arnhold IJ \& Jorge AA.
Genetic predictors of long-term response to growth hormone (GH) therapy in children with GH deficiency and Turner syndrome: the influence of a SOCS2 polymorphism. Journal of Clinical Endocrinology and Metabolism 201499 E1808-E1813. (https://doi.org/10.1210/ jc.2014-1744)

19 Bianco B, Verreschi IT, Oliveira KC, Guedes AD, Galera BB, Galera MF, Barbosa CP \& Lipay MV. PTPN22 polymorphism is related to autoimmune disease risk in patients with Turner syndrome. Scandinavian Journal of Immunology 201072 256-259. (https://doi. org/10.1111/j.1365-3083.2010.02438.x)

20 Villanueva-Ortega E, Ahedo B, Fonseca-Sánchez MA, Pérez-Durán J, Garibay-Nieto N, Macías-Galavíz MT, Trujillo-Cabrera Y, GarcíaLatorre E \& Queipo G. Analysis of PTPN22, ZFAT and MYO9B polymorphisms in Turner syndrome and risk of autoimmune disease. International Journal of Immunogenetics 201744 153-157. (https://doi. org/10.1111/iji.12323)

21 Peralta López M, Centeno V, Miras M, Silvano L, Pérez A, Muñoz L, Sobrero G, Ulla M \& Tolosa de Talamoni N. Association of vitamin $\mathrm{D}$ receptor gene Cdx2 polymorphism with bone markers in Turner syndrome patients. Journal of Pediatric Endocrinology and Metabolism 201225 669-671. (https://doi.org/10.1515/jpem-2012-0098)

22 Santos LOD, Bispo AVS, Barros JV, Laranjeira RSM, Pinto RDN, Silva JA, Duarte AR, Araújo J, Sandrin-Garcia P, Crovella S, et al. CTLA-4 gene polymorphisms are associated with obesity in Turner syndrome. Genetics and Molecular Biology 201841 727-734. (https:// doi.org/10.1590/1678-4685-GMB-2017-0312)

23 Massart F, Marini F, Bianchi G, Minisola S, Luisetto G, Pirazzoli A, Salvi S, Micheli D, Masi L \& Brandi ML. Age-specific effects of estrogen receptors' polymorphisms on the bone traits in healthy fertile women: the BONTURNO study. Reproductive Biology and Endocrinology 20097 32. (https://doi.org/10.1186/1477-7827-7-32)

24 McGuigan FE, Murray L, Gallagher A, Davey-Smith G, Neville CE, Van't Hof R, Boreham C \& Ralston SH. Genetic and environmental determinants of peak bone mass in young men and women. Journal of Bone and Mineral Research 200217 1273-1279. (https://doi. org/10.1359/jbmr.2002.17.7.1273)

25 Almeida M, Laurent MR, Dubois V, Claessens F, O'Brien CA, Bouillon R, Vanderschueren D \& Manolagas SC. Estrogens and androgens in skeletal physiology and pathophysiology. Physiological Reviews 201797 135-187. (https://doi.org/10.1152/ physrev.00033.2015)

26 Herrington DM, Howard TD, Brosnihan KB, McDonnell DP, Li X, Hawkins GA, Reboussin DM, Xu J, Zheng SL, Meyers DA, et al. Common estrogen receptor polymorphism augments effects of hormone replacement therapy on E-selectin but not C-reactive protein. Circulation 2002105 1879-1882. (https://doi. org/10.1161/01.cir.0000016173.98826.88)

Received in final form 28 October 2019

Accepted 31 October 2019

Accepted Preprint published online 31 October 2019 https://ec.bioscientifica.com https://doi.org/10.1530/EC-19-0398
(C) 2019 The authors Published by Bioscientifica Ltd
This work is licensed under a Creative Commons Attribution-NonCommercial-NoDerivatives 4.0 elnternationad ticense ifica . com at 04/26/2023 11:07:01AM 